\title{
Implementation Of Electronic Money In Developing Payment Transactions Through Islamic Economic Perspective
}

\author{
Abdul Majid Toyyibi \\ Sekolah Tinggi Agama Islam (STAI) Al Fithrah Surabaya, Indonesia \\ abdulmajidtoyyibi93@gmail.com
}

\begin{abstract}
Purpose - By upholding the value of sharia principles economic activities. Electronic money is a financial transaction that is used by the community as a substitute for cash, and ottopay is part of it, to help become a financial intermediary with an electronic system through QR and billers.
\end{abstract}

Method - The research is based on researching ottopay in its transactions by usinga descriptive qualitative.

Result - From the research method process used in the study resulted in the study that the implementation of ottopay in topping up by filling directly via the bank ATM or through an agent by clicking the wallet menu then top up and following the steps until the confirmation is successful and the balance is ready whenever it can be used.

Implication - The existence of the Ottopay system is a support for the community to be able to think forward in the world of finance and technology, in addition, ottopay can be used as a business opportunity to provide benefits in the form of added value in the form of turnover that can be owned by merchants and can be used as additional income for the community.

Originality - The implementation of ottopay between users and publishers and users and merchants is in accordance with the rules of the DSN MUI fatwa, therefore the benefits of the ottopay application can guarantee security, easy and practical use so that people's economic turnaround is faster because it has an electronic digital system.

Keywords: Electronic Money; Ottopay; Islamic Economics. 
Abdul Majid Toyyibi

\section{Introduction}

Islam prioritizes charity over ideas, said Mohammad Iqbal in The Reconstruction of Religious Thought in Islam, that Islam can be recognized as a civilization. Islam exists for not only as a religious idea, but as a seed and a cosmopolitan model of civilization. The Qur'an is not just a doctrine, but a call to express affection in deeds. Piling up wealth is not good and goodness is to share wealth evenly and to create a just society where the poor and weak are treated with respect. (M. Anton Athillah, 2008)

Islam teaches its adherents to help people who need a help, where the Messenger of Allah said: "fellow Muslims are brothers, do not tyrannize each other, anyone who fulfils the needs of his brother, then Allah will replenish his needs, and anyone who helps reduce the burden of his fellow brothers, then Allah will remove his burden on the Day of Resurrection."The spirit of this hadith provides guidance not to exploit fellow Muslim brothers who are in need of something; we must not take advantage of other people's situation for personal gain. For this reason, the Messenger of Allah forbids us making transactions with people who desperately need hands, Allah said: give just weight and measure and diminish not to men their things. (Dimyauddin, 2015)

The economic practice that is taught in Islam is a guide for Muslims that Islam is not only about prayer, but Islam teaches us how to run good and right economic practice. All are taught in muamalah and it can be seen that economics is a religious activity that is one of the duties for people to be able to meet their needs in the right corridor through the principles contained in sharia. All the provisions of the Qur'an and Sunnah have the essential benefits of realizing human benefit. It is because the Qur'an is from Allah who is very knowledgeable about human nature and desires, and the As-Sunnah is for the Prophet who had received guidance from Allah SWT. The values contained in the Qur'an are in the form of commands, prohibitions, recommendations, stories of the prophets, stories of previous people, which surely must have direct and indirect benefits for mankind. Manifesting human benefit in Islam 
Implementation Of Electronic Money In ...

is known as Maqashidus Sharia. The meaning is the purpose and objective of the existence of Islamic law which is for the goodness and welfare of humanity in the world and the hereafter. To achieve this goal there are five main elements that must be maintained, that those are maintaining religion, life, wealth, mind and offspring. (Sri Nurhayati, 2011)

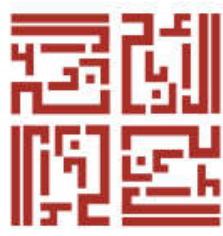

Today's global economy is to make capitalist economy as a foothold for the welfare of a country. The capitalist system is basically one system that does not have the aim to prosper the community, because there is no a single sentence stating that it will prosper the community. (M Sulaeman Jajuli, 2016) from this, academics see the cruel side of capitalists who are thirsty for economic power, very inhumane and far from social life principle in the economic community. Therefore, the existence of the Islamic economic system can invite the stratum to a regulated life which is expected by Islam that economic life should establish a fair value of humanity as explained in the detailed points of Pancasila.

Current economic development is balanced with technological progress in the frame with the Ottopay application, indicating a forward-thinking mindset of society to be able to cope with these developments. This is done because the public can obtain the benefit, so that the application users registered with electronic money respond with a positive response from an enthusiastic, and it can be seen on just before the Eid Fitri celebration which the majority of all shopping transactions uses electronic money paying systems.

It is a situation which people - owner of a company or an starting-up entrepreneur - leave the offline system in various sectors using payment transactions. Despite this situation, the community is required to understand technology in order to deal with the current situation. This is actually not new when looking at other countries that have been doing electronic transactions from all sectors. People Republic of China for example, the people no longer carry cash in making purchases for clothes or food and so on. However, the system will have a positive impact on a good change in the economy of a 
Abdul Majid Toyyibi

country, especially when people can easily go with this development, so the acceleration of economic growth is faster.

Indonesian people, especially in the East Java region of Surabaya Sidoarjo, on the nuances of Ramadan and Eid, which incidentally are discount hunters, choose to use electronic money because many cash backs provided by various existing electronic money applications. Therefore, the existence of the application has at least two impacts, positive and negative. Positive side is intended for merchants who are ready to accept non-cash payments and are incorporated in certain electronic money. And negative for merchants who are not ready to accept payment changes because the system still maintains the originality of cash payments. From both of them we can see the difference from the growth and level of the crowd.

\section{Literature Review}

\section{Electronic Money}

The use of cash is now beginning to be abandoned by urban communities because they consider that security is the main concern so that they can avoid undesired things such as theft and so forth. The use of cash is considered to be free of cost, practical and efficient, but its use in large quantities can create a burden to the economy, especially related to cash handling and low velocity off money. (Hidayat, 2006) Community activities today are becoming more modern along with economic and technological advancements. Such circumstances bring a mindset that is completely instant and practical so that the exchange of goods and services run quickly in line with its development.

With its all-round financial transactions, researchers assume that it has a correlation with the concept of time value of money. The theory explains that the NWU is one of the basic frameworks of thought towards a decision and policy in modern finance. Simply, it can be said that money has a time value. For example Rp. 1,000,000.00 is not currently the same value as 100,000,000 over the next year. A rational individual would prefer a sum of Rp. $1,000,000.00$ today compared to Rp. $1,000,000.00$ one more year. The reason 
Implementation Of Electronic Money In ...

for this thought is that if someone receives Rp. 1,000,000.00 today, then he can invest (saving at the bank) with a profit rate of $10 \%$ for example, so later he will get money Rp. 100,000.00 as a year profit sharing. Therefore Rp. $1,000,000.00$ today is equivalent to Rp. $1,100,000.00$ after one year later when the profit sharing rate is $10 \%$. Thus, money is considered to have time

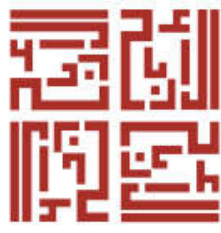
value. (Najmudin, 2011)

When referring to Bank Indonesia, the total money supply for electronic money issued by BI in 2018 in December was 167,205,578 and in 2019 in April it was 197,413,945. (Bank Indonesia, 2019) money circulating every month continues to rise and this is evidenced by data from Bank Indonesia which shows an increasing trend. This shows that Indonesian people consider that electronic money is important. this also shows that the public already knows the benefits of using the electronic money application.

One of the payment systems that can be utilized to compete with current economic developments is the non-cash payment system. Non-cash payment systems have many benefits which are certainly needed in this modern era. Emoney is one of the products of the non-cash payment system that in recent years is being intensively introduced to the people of Indonesia. Some countries such as Hong Kong, Malaysia, and Singapore have successfully developed e-money products that show a significant potential to reduce the growth rate of cash usage, especially for payments that are micro to retail (Hidayati, 2006).

In principle, people who have the same e-money as they have a cash amount that is converted into electronic form. (Quthbi 2016) In the provisions of Bank Indonesia Regulation Number 11/12 / PBI / 2009 concerning Electronic Money, 3 provisions in Article 1 Paragraph 3: "Electronic Money (Electronic Money) is a payment instrument issued on the basis of the value of money paid in advance by the holder to the publisher ". Along with these developments the government began to do things to improve the economy of a country. In 2006 the Directorate of Accounting and Payment Systems (DASP), regarding the Grand Design of Efforts to Increase the Use of Non-cash Payments or referred to as Toward a Less Cash Society 
Abdul Majid Toyyibi

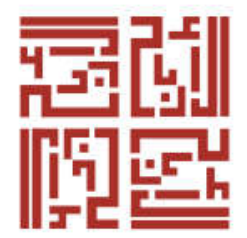

AL-ARBAH | 24

(LCS), conducted an activity to review the continued operation of e-money. Bank Indonesia issued e-money in 2009, and to support the payment of LCS Bank Indonesia made a national movement issued on August 14, 2014 to increase the amount of electronic money used. This movement is called the National Non-Cash Movement (GNNT) whose main purpose is for the safety and comfort of the community. GNNT seeks to reduce the money printing budget, prevent corruption, money laundering and terrorism financing. One of GNNT's efforts to carry out its objectives is to use e-money. Provisions regarding e-money have also been accommodated in Bank Indonesia Regulation No. 7/52 / PBI / 2005 concerning the Implementation of CardBased Payment Instrument Activities. (Hidayati, 2006)

In Islamic teachings, the natural resources on this earth are unlimited. God created the universe and its contents with an uncountable amount. Basically Electronic money is the same as money as usual because it has a function as a means of payment in buying and selling goods. In the perspective of Islamic economics electronic money is halal as easy as not to get out of the corridor of the principles set out in sharia. This halal is based on a rule that every transaction in muamalah on its basis is permissible unless there is an argument forbidding it, since then the law has changed to become haram, so that electronic money must meet the criteria and even provisions in accordance with sharia principles. Another factor that becomes a consideration that electronic money is halal is because of the demands of human needs for electronic money, and consideration of the many benefits that are in it.

\section{E-Money in Islam}

At present several Sharia Banks have also issued products related to electronic money. They will not dare to launch the product unless they have the support of the financial services authority (OJK) and the Indonesian Ulema Council (MUI) - through the fatwa of the National Sharia Council. This means that electronic money is legitimately used both according to religion 
Implementation Of Electronic Money In ...

and state. Furthermore, E-Money practitioners or companies are engaged in developing and inviting the public to take part in E-Money activities.

The contract used in electronic money transactions according to DSN MUI is the wadiah contract or the qard contract. Wadiah contract is a pure deposit that must be maintained and returned at any time in accordance with the wishes of the owner. (Adiwarman Karim, 2014) this means that when consumers or merchants top up the ottopay balance, they assume that the money is deposited into ottopay and whenever they need it to pay shopping or pay bills then the balance money must be able to be used.

Sometimes the contract uses a qard contract, which is the provision of assets to other people that can be invoiced or demanded according to the amount of money lent, without any additional or requested compensation. (Ismail, 2014) the contract referred to in electronic money transactions is the application using top up funds with the permission of the account owner by returning top up funds as the account owner needs without any compensation. The development of the Islamic system economy is no longer a scoff in the community that holds that the economy of the Islamic system is only by name or label, but its existence is strengthened by the support of the Indonesian Ulema Council (MUI) through the fatwa of the national sharia council which shows its true seriousness in carrying economic systems that are taught by Islam to the public, companies, and even provide training to economic actors to be educated using the actual Islamic economic system. This development is in line with the economic situation of the people who are demanded to advance the Islamic system in the business sector in order to avoid the cruel ribawi system according to the community.

To run Ottopay products, the owner or business actors must have Islamic economic principles. The first is to have the universal principles of monotheism, justice, nubuwwah, khilafah and results. The second principle is the principle of derivatives is the principle of Islamic economic systems that are also the pillars of Islamic economics. And the third principle is the akhlah which is embedded in the minds of people who contribute to transactions 
Abdul Majid Toyyibi

because the Islamic economic system only ensures that there are no transactions that contradict with the Shari'a. (Vinna Sri Yuniarti, 2016)

As a reference in conducting research, Nisa in a study of electronic money explained that: (1) There is a positive influence on the level of understanding of e-money on the interest in using e-money in the community who owns electronic money or e-money in the Tanah Abang area indicated by the value regression coefficient of 0.715 , which the significance value is smaller than the level of significant $(0,000<0.050)$, and the coefficient of determination $\mathrm{r} 2$ of 0.367 (2) There is a positive influence of Utilization Interest in Using Emoney in the community that owns electronic money or E-money in the region Tanah Abang as indicated by the regression coefficient value of 0.910 , which the significance value is smaller than the level of significant $(0,000$ $<0.050$ ), and the coefficient of determination $\mathrm{r} 2$ of 0.782; (3) There is a positive influence on the level of understanding of E-money and Utilization in line with the Interest in Using E-money in the community who owns electronic money or E-money in the Tanah Abang region as indicated by the coefficient of determination (Adjusted 2) of 0.789 or $78.9 \%$ which means that the Interest in Using E-money in the Community of Electronic Money Owners or E-money in Tanah Abang can be explained by a variable of Understanding and Convenience of 78.9\%. (Nira Indhira Vhistika, 2017) Furthermore, Rifky also explained in his research that with electronic money the public is given security and comfort in carrying money, so that when they want to make transactions in large amounts of money, people only carry one card needed to carry money in large quantities. (Rifky Tazqiyaturrohmah, 2016) from previous research, this tells us that electronic money is useful and even useful because it can minimize something that is not wanted so that security is guaranteed. On the other hand electronic money will also have an impact on the economy of the community because the rapid flow of money shows the economic condition of a region.

Ottopay is electronic money used by merchants to conduct financial transactions and make bill payment transactions. Its existence provides answers to the difficulties of finding and minimizes the culture of queuing in 
Implementation Of Electronic Money In ...

certain places when they want to pay several monthly bills. And indirectly the community has been influenced by technology whose benefit value can be accepted widely by public. From some of the explanations above, this study will examine the implementation of ottopay transactions and a review of the contracts used by ottopay.

Basically, the explanation above leads to several studies on the implementation of ottopay and a review of the contract used by ottopay in transaction payments, so that later researchers will meet directly with consumers and merchants of ottopay themselves. For the achievement of a credible study, the data used from this study are very important. Data obtained by researchers are those generated from the field through direct observation techniques called primary data and secondary data obtained from ottopay in the form of a guidebook and so forth. It is hoped that this will become a useful research for academics and society in general. Therefore, the research techniques used consisted of a study approach, research location, data collection and data analysis. From the research techniques used above directing this research in the form of case studies with descriptive analysis.

In research there are two approaches, qualitative approach and quantitative approach. In this study, researchers used a qualitative approach. According to Bogdan and Taylor, qualitative methodology is a research procedure that produces descriptive data in the form of written or oral words from people and observable behaviour. In line with this definition, Kirk and Miller define that qualitative research is a particular tradition in social science that is fundamentally dependent on human observations both in the region and in terms of it (Lexy J. Moleong, 2008) in this study not only based on data obtained but more than that related to the implementation or practice that brings the value of the merchant's economy to develop its business more safely and in a contract that is transacted there in. 
Abdul Majid Toyyibi

\section{Methods}

The next step is data collection. This step is important so that everything that becomes a problem of research can be answered with facts and data obtained from this research. Therefore, the data collection used in this study follows what Sugiyono said. This method includes 3 techniques namely observation, interview, and documentation. (Anis Fuad, 2014) at the observation stage researchers must have done it during the grand tour of observation so that researchers found meaning or behaviour in the study. The interview used by researchers was to directly meet with ottopay merchants in order to obtain accurate information and detailed descriptions of their transaction activities. Included in the collection of documentation data, it was possible for the research to conduct trivial cracks from several sources of documentation data. this is intended to give an idea in the next stage that is the form of data analysis during the study, whether the various problems were answered or not.

\section{Discussion}

Ottopay is a modern non-cash payment application with a QR code that helps sellers and buyers make easier, safer and more convenient transactions. One ottopay QR can be used to accept various payment applications from various QR applications. Besides ottopay can be used to sell pulses, data packages, pay bills and electricity tokens, BPJS, and other bills. Applications that have cooperated are Jakone mobile, Iyap, Confident, Bris, and OCBC NISP.

$\mathrm{QR}$ code (quick response) is a code whose purpose is to convey information quickly to get a fast response as well. Unlike barcode bar codes that only store information horizontally, QR codes are able to store information horizontally and vertically. Therefore, QR codes can automatically hold more information than bar codes. QR code has the advantage that the first has a high capacity in coding data that is capable of storing all types of data; the second has a smaller display than a barcode; and the third is resistant to damage because the QR code is able to correct errors 
Implementation Of Electronic Money In ...

up to 30\%.Thus, even though some QR code symbol dirty or corrupt, data can still be read.

The advantages of using ottopay are practical, able to increase income, and able to receive $\mathrm{QR}$ payments as well as sales reports and easiness to top up and withdraw. From a simple and advantageous Ottopay, there is payment process like to scan QR sticker at the merchant, to enter the nominal amount to be paid, to enter the PIN (the same as the login PIN), to click ok, and when the payment is successful, buyer's balance in your wallet decreases and moves to the turnover at the merchant's turnover.

Along with the increasing response of modern society today, ottopay as one of the aggregators of payment providers via QR code continues to expand its strategy by working with True Money Indonesia in conducting non-cash transactions using the True Money application in all merchants that cooperate with ottopay. This cooperation eases consumers to access payment transactions. Merchant payments are now easier for True Money users because active merchants can receive payments from True Money. Hence not only ottopay users can make payments with QR, but True Money consumers can also access it in a simple way, just by scanning, then entering the nominal and showing proof of payment to the cashier.

The ottopay transaction contract review is intended to investigate that whether this non-cash payment transaction goes through the right domain and is avoided from ribawi, so that the transaction is worth barakah (blessing in Muslim). This is seen from when the balance is filled to be made payment to when the user makes a biller purchase in accordance with an existing contract in the Islamic economy. When referring back to the MUI DSN fatwa that electronic money may be used as a means of payment by following the provisions contained in this fatwa as follows 1) The contract between the issuer and the electronic money holder is a wadiah contract or a qard contract. Wadiah contract terms and conditions are as follows 1 . The nominal amount of electronic money is for safekeeping, which can be taken or used by the holder at any time; 2 . The nominal amount of electronic money deposited may not be used by the depositor except with the permission of the holder; 3 . 
Abdul Majid Toyyibi

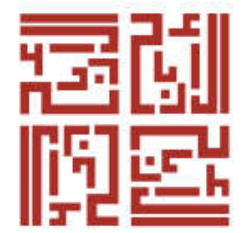

AL-ARBAH | 30

The nominal amount of electronic money entrusted is used by the issuer with the permission of the holder. In this case, the deposit agreement is changed to a loan agreement (qard) and the responsibility of the depositor is the same as the responsibility in the qard contract; 3 . The relevant authorities are obliged to restrict issuers from using deposit funds from card holders; 4 . The use of funds by the issuer must not be in conflict with Islamic principles and regulations. 2) In the event that the contract used is a qard contract, the following terms and conditions apply for the qard contract: 1 . The nominal amount of electronic money is debt that can be taken or used by the holder at any time; 2. Issuers can use debt money from electronic money holders; 3. Issuers are required to return the principal amount of the electronic money receivable at any time in accordance with the agreement; 4 . The relevant authorities are obliged to limit issuers in the use of loan funds from card holders

The use of funds by the issuer must not be in conflict with Islamic principles and statutory regulations. Contracts that the issuer can use with the parties in the administration of electronic money (principal, acquirer, trader or merchant, clearing organizer, and final settlement provider) are ijarah contracts, jualah contract, and wakalah bi al ujrah contracts. 1) In the case of the contract used for the ijarah contract, the terms and limitations of the ijarah agreement apply as specified in the DSN MUI number 112 / DSNMUI / IX / 2017 concerning the ijarah contract. 2) In the case of a contract that is also used for a contract, the terms and limitations of the contract also apply, as contained in DSN-MUI number 62 / DSN-MUI / XII / 2007 concerning the contract. 3) In the case of the contract used is a wakalah bil ujrah contract, then the terms and limitations of the wakalah bil Ujrah agreement as contained in DSN-MUI number 113 / DSN-MUI / IX / 2017 concerning wakalah bil ujrah. (DSN-MUI)

Aagreements that can be used between publishers and digital financial service agents are ijarah contracts, ju'alah contracts, and wakalah bi al-ujrah contracts. 1) In the case of the contract used is the ijarah contract, it is contained in DSN-MUI Number: 112 / DSN-MUI / IX.2017 concerning the 
Implementation Of Electronic Money In ...

ijarah contract. 2) In the case of a contract used isju'alah contract, the terms and limitations of the juvenile contract apply as contained in DSN-MUI Number: 62 / DSN-MUI / XII / 2007 concerning ju'alah contract 3) In the case of the contract used is a bi al-ujrah wakalah contract, then the terms and limitations of the bi al-ujrah wakalah agreement as contained in DSN-MUI

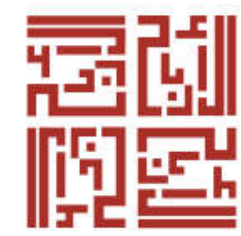
Number: 113 / DSN-MUI / IX / 2017 concerning bi al-ujrah wakalah

Aagreements that can be used between publishers and digital financial service agents are ijarah contracts, ju'alah contracts, and wakalah bi al-ujrah contracts. 1) In the case of the contract used is the ijarah contract as contained in DSN-MUI Number: 112 / DSN-MUI / IX.2017 concerning the ijarah contract. 2) In the case of a contract used is ju'alah contract, the terms and limitations of the juvenile contract apply as contained in DSN-MUI Number: 62 / DSN-MUI / XII / 2007 concerning ju'alah contract. 3) In the event that the contract used is a bi al-ujrah wakalah contract, then the terms and limitations of the bi al-ujrah wakalah agreement as contained in DSN-MUI Number: 113 / DSN-MUI / IX / 2017 concerning bi al-ujrah wakalah

The provision of facility service fees in the operation of electronic money, the issuer may charge the service fees for electronic money to holders with the following conditions: 1 . Facility service fees must be in the form of real costs to support the smooth running of electronic money; 2. Imposition of fees - facility service fees must be properly delivered to cardholders in accordance with sharia and the prevailing laws and regulations.

Provisions and limitations on the operation and use of electronic money must avoid: 1). Ribawi transactions, gharar, maysir, tadlis, risywah, and israf. 2). Transaction on illicit or immoral objects. The special provisions in the form of a nominal amount of electronic money at the issuer must be placed in an Islamic bank, and in the case of cards used as electronic money lost, the nominal amount of money at the issuer may not be lost. If a dispute resolution occurs, for example if one party does not fulfil its obligations or if there is a dispute between the parties, then the settlement is carried out through a dispute resolution institution based on sharia according to the laws and regulations prevailed only if no agreement is reached through consultation. 
Abdul Majid Toyyibi

From the explanation of the MUI DSN fatwa number 116 / DSN-MUI / IX / 2017, the researcher examines the results of the study by synchronizing the data of the MUI DSN fatwa that serves as a reference for a sharia-based transaction. Researchers assume that when viewed from the side of the application holder in charging top up for payment transactions that are on the ottopay menu, this process illustrates the existence of a process that is right according to sharia. It can be seen from every balance that the wadiah contract used - by the DSN MUI, and in each transaction, the application user balance can be directly processed which makes the sequence or the process in the transaction between the user and the issuer appropriately runs with the DSN-MUI rules.

One thing that is also important is that the government through the fatwa of DSN MUI recommend when making a transaction, the process must be avoided from ribawi and involve Islamic banks in topping up balances. This is intended to make Islamic banks not only to finance, but also to follow the demands of the current era. The development of ottopay is a key part that can help the economic situation and increase people's income. when viewed from the side of the merchants, they are free to sell as many products as possible according to their turnover they set themselves, so that the freedom of the merchants can be obtained in accordance with the management of their business. Then when viewed from the user side, currently, unemployment in Indonesia continues to increase every period and this is a concern of the community in matters of crime, especially in crowded places. Therefore, the presence of ottopay provides a value that benefits not only in the form of benefit but also the level of security. From the above analysis, it can be concluded that the balanced economic development of the community surge up as the development of electronic money in the form of Ottopay. Its presence brings a progress to the community both in income and at the level of a digital mindset, and this causes people to adjust to current technology because they see great value of benefits and can be enjoyed immediately when many promos are issued by related companies. 
Implementation Of Electronic Money In ...

From the results of this study, this development can knit back the position of financial transactions in Islam, that Islam does not mean merely ritual worship, but is the position and obedience of a servant to Allah SWT as a whole to reach the ladder / higher degrees of peace and prosperity, happiness and safety. Islam also provides its followers with complete rules and guidelines in practicing worship at the same time in this life. The rule consists of three things namely: creed, sharia and morals. One part of sharia is to regulate how to carry out economic activities, and to include the obligation to conduct economic transactions in sharia. All sharia rules are presented into five Islamic laws and it has the aim to be able to purify the soul, uphold justice and obtain the benefit of religion, soul, mind, descent and wealth to save the world and the hereafter.

\section{Conclusion}

Ottopay's existence is a support for the community to be able to think forward in the world of technology and finance, besides that it provides additional turnover that can be owned by merchants when selling billers and the income can be an additional capital for the community to be used as a business opportunity. From the next research, the researcher wants to reveal an aspiration that should be examined by academics that this newborn ottopay needs to be explored regarding discounts obtained by business people or consumers when making transactions.

Existing competitors have different strategies, but we must be able to look for loopholes so that the strategy used by ottopay can divert the view of competitors or can add agents who are ready to join ottopay with various interests that exist in ottopay products themselves. Then the last thing in this paper is that researchers feel this study is far from perfection so there needs to be criticism that can wake researchers to be better in the future. Referring to this, the researcher felt the importance of a criticism or suggestion in this writing. 
Abdul Majid Toyyibi

\section{References}

Athoillah M Anton. Islamic Economic Philosophy. Yogyakarta : Sahifa Press.

Djuwaini Dimyauddin. 2015. The introduction of Fiqh Muamalah. Yogyakarta: Pustaka Pelajar.

AL-ARBAH | 34 Fatwa DSN-MUI Nomer 116/DSN-MUI/IX/2017.

Jajuli, M, Sulaeman. 2015. Islamic economy Umar bin Khattab. Yogyakarta : Deepublish.

Hidayat. 2006. Efforts to increase the use of non-cash payment instruments through the development of E-money. Bank Indonesia.

Hidayati, S. 2006. Operational E-money. Bank Indonesia.

Quthbi, Z, H. 2016. The effect of convenience, benefits, security and privacy of information sufficiency and the pleasure of making transactions with the decision to use E-money on the Jogja trans bus. Thesis. Yogyakarta : economics and business faculty, State Islamic university Sunan Kalijaga.

Tazkiyyaturrohmah Rifky. 2016. Electronic Money Transactions in terms of Islamic Business Law. Thesis. Yogyakarta : Fakultas Economics dan Business Faculty State Islamic University Sunan Kalijaga.

Vhistika, Nisa, Indira. 2017. The Effect of E-Money Understanding Level and Utilization on Interest in Using E-Money in the Tanah Abang area. Minithesis : Fakultas Ekonomi Universitas Negeri Yogyakarta.

Karim, adiwarman. 2014. History of Islamic Economic thought. Jakarta : Rajawali Pers.

Najmuddin. 2016. Financial Management and Actualization of Modern Syar'iyyah. Yogyakarta : Penerbit Andi.

Nurhayati Sri. 2011.Islamic Accounting in Indonesia. Jakarta : Salemba Empat.

Ismail. 2014. Syariah Banking. Jakarta : Kencana.

Moleong, Lexy J. 2008. Qualitative Research Methodology. Bandung : PT Remaja Rosdakarya. 